\section{Kidney \\ Blood Pressure Research}

Original Paper

\title{
SPAK Dependent Regulation of Peptide Transporters PEPT1 and PEPT2
}

\author{
Jamshed Warsi Luo Dong Bernat Elvira Madhuri S Salker Ekaterina Shumilina \\ Zohreh Hosseinzadeh Florian Lang
}

Department of Physiology I, University of Tübingen, Gmelinstr. 5, 70276 Tübingen, Germany

\section{Key Words}

Peptide transport $•$ Cell volume $\bullet$ Intestine $\bullet$ Knockout mice

\begin{abstract}
Background/Aims: SPAK (STE20-related proline/alanine-rich kinase) is a powerful regulator of renal tubular ion transport and blood pressure. Moreover, SPAK contributes to the regulation of cell volume. Little is known, however, about a role of SPAK in the regulation or organic solutes. The present study thus addressed the influence of SPAK on the peptide transporters PEPT1 and PEPT2. Methods: To this end, cRNA encoding PEPT1 or PEPT2 were injected into Xenopus laevis oocytes without or with additional injection of cRNA encoding wild-type, SPAK, WNK1

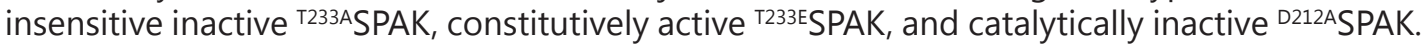
Electrogenic peptide (glycine-glycine) transport was determined by dual electrode voltage clamp and PEPT2 protein abundance in the cell membrane by chemiluminescence. Intestinal electrogenic peptide transport was estimated from peptide induced current in Ussing chamber experiments of jejunal segments isolated from gene targeted mice expressing SPAK resistant to

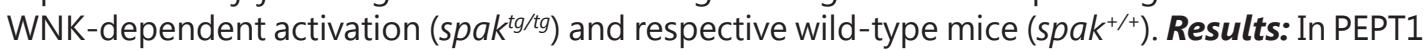
and in PEPT2 expressing oocytes, but not in oocytes injected with water, the dipeptide gly-gly (2 $\mathrm{mM}$ ) generated an inward current, which was significantly decreased following coexpression of

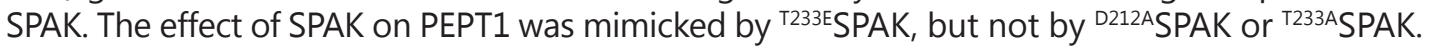
SPAK decreased maximal peptide induced current of PEPT1. Moreover, SPAK decreased carrier protein abundance in the cell membrane of PEPT2 expressing oocytes. In intestinal segments gly-gly generated a current, which was significantly higher in $s p a k^{\text {tg/tg }}$ than in $s p a k^{+/+}$mice. Conclusion: SPAK is a powerful regulator of peptide transporters PEPT1 and PEPT2.
\end{abstract}




\section{Kidney \\ Blood Pressure Research}

Kidney Blood Press Res 2014;39:388-398

\begin{tabular}{l|l}
\hline DOI: 10.1159/000368451 & (C) 2014 S. Karger AG, Basel
\end{tabular}

Published onlıne: October 30, 2014

www.karger.com/kbr

Warsi/Dong/Elvira/Salker/Shumilina/Hosseinzadeh/Lang: SPAK Sensitive PEPT1/2 Activity

\section{Introduction}

Cellular accumulation of nutrients involves a wide variety of carriers including the peptide transporters 1 (PEPT1) and 2 (PEPT2), which accept di- and tripeptides [1-3] as well as peptide-like drugs $[1,2]$. PEPT1 is a high-capacity, low-affinity peptide transporter and PEPT2 a low-capacity, high-affinity peptide transporter [4]. PEPT1 and PEPT2 are both expressed in the renal proximal tubule $[4,5]$. PEPT1 is mainly expressed in early parts of the proximal tubule, whereas PEPT2 prevails in latter parts of the proximal tubule [4]. PEPT1 is the major peptide transporter expressed in intestine [4]. PEPT2 is expressed by neurons and glial cells of cerebral cortex, olfactory bulb, basal ganglia, cerebellum and hindbrain as well as epithelial cells of the choroid plexus and ependymal cells [4]. PEPT1 is further expressed in the pancreas, bile duct and liver, and PEPT2 in the lung, mammary gland and spleen [4]. The peptide transporters are regulated by several hormones including leptin [6] and growth hormone [7].

Kinases hitherto identified in the regulation of peptide transporters include phosphoinositide (PI) 3 kinase [8], phosphoinositide dependent kinase PDK1 [8], serum \& glucocorticoid inducible kinase SGK1 [9] and AMP activated kinase [10]. Kinases involved in the regulation of epithelial transport include SPAK (STE20-related proline/alanine-rich kinase) [11-13]. SPAK is regulated by with-no-K(Lys) (WNK) kinases [11, 14-17], which are powerful regulators of renal tubular ion transport and blood pressure [18-22]. Specifically, SPAK and the related oxidative stress-responsive kinase 1 (OSR1) kinase upregulate the $\mathrm{Na}^{+}, \mathrm{Cl}^{-}(\mathrm{NCC})$ and the $\mathrm{Na}^{+}, \mathrm{K}^{+}, 2 \mathrm{Cl}^{-}$(NKCC2) cotransporters [14, 15, 18, 23-33]. Mutations of genes encoding WNK kinases underly Gordon's syndrome, a monogenic disease leading to hypertension and hyperkalaemia $[16,17,34,35]$. By regulation of ion transport, SPAK contributes to cell volume regulation $[24,36]$. Most recent observations pointed to a role of OSR1 and/or SPAK in the regulation of $\mathrm{Na}^{+}$coupled phosphate transport $[37,38]$, and $\mathrm{Na}^{+} / \mathrm{H}^{+}$exchanger [39], pointing to a broader role of those kinases in the regulation of epithelial transport. To the best of our knowledge, nothing is hitherto known about a role of SPAK in the regulation of peptide transporters.

The present study thus explored whether SPAK influences the function of PEPT1 and/ or PEPT2. To this end, cRNA encoding the peptide transporters were injected into Xenopus laevis oocytes with or without cRNA encoding SPAK and peptide transport quantified by determination of peptide induced current. To define the in vivo significance of SPAK sensitive peptide transport regulation, peptide induced current was determined in Ussing chamber experiments of intestinal segments isolated either from gene targeted mice expressing SPAK resistant to WNK-dependent activation $\left(\right.$ spak $\left.^{\text {tg/tg }}\right)$ mice or from corresponding wild-type $\left(\right.$ spak $\left.^{+/+}\right)$mice.

\section{Materials and Methods}

\section{Constructs}

Constructs encoding rabbit PEPT1, rabbit PEPT2 and haemagglutinin labelled PEPT2-HA [40], wildtype SPAK, WNK1 insensitive inactive ${ }^{\mathrm{T} 233 \mathrm{~A} S P A K}$, constitutively active ${ }^{\mathrm{T} 233 \mathrm{E}} \mathrm{SPAK}$, and catalytically inactive

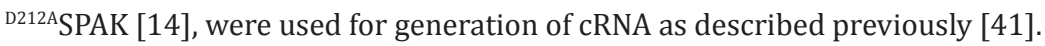

Voltage clamp in Xenopus laevis oocytes

Xenopus laevis oocytes were prepared as previously described $[42,43]$. Where not indicated otherwise,

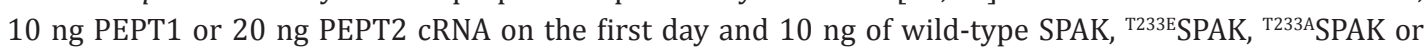
${ }^{\mathrm{D} 212 \mathrm{~A} S P A K}$ CRNA were injected on the same day after preparation of the oocytes [44]. The oocytes were maintained at $17^{\circ} \mathrm{C}$ in ND96 solution containing (in mM): $88.5 \mathrm{NaCl}, 2 \mathrm{KCl}, 1 \mathrm{MgC1}, 1.8 \mathrm{CaC} 1_{2}, 2.5 \mathrm{NaOH}$, 5 HEPES (pH 7.4) and 5 sodium pyruvate $\left(\mathrm{C}_{3} \mathrm{H}_{3} \mathrm{NaO}_{3}\right)$. pH7.4. Gentamycin (100 mg/l), Tetracycline (50 mg/l), 


\section{Kidney \\ Blood Pressure Research}

Kidney Blood Press Res 2014;39:388-398

\begin{tabular}{l|l}
\hline DOI: 10.1159/000368451 & (c) 2014 S. Karger AG, Basel
\end{tabular}

Published onlıne: October 30, 2014

www.karger.com/kbr

Ciprofloxacin (1.6 mg/l), and Theophiline $(90 \mathrm{mg} / \mathrm{l})$ were added. Where indicated, Brefeldin A (5 $\mu \mathrm{M})$ was added to the respective solutions. The experiments were performed at room temperature 3 to 4 days after injection. Two-electrode voltage-clamp recordings were performed at a holding potential of $-70 \mathrm{mV}$. The data were filtered at $10 \mathrm{~Hz}$ and recorded with a Digidata A/D-D/A(1322A Axon Instruments) converter and Clampex 9.2 software for data acquisition and analysis (Axon Instruments). The control superfusate (ND96) contained (in mM): $93.5 \mathrm{NaCl}, 2 \mathrm{KCl}, 1.8 \mathrm{CaCl}_{2}, 1 \mathrm{MgCl}_{2}, 2.5 \mathrm{NaOH}$ and $5 \mathrm{HEPES}$ ( $\mathrm{pH}$ 7.4). Glycine-glycine was added to the solutions at a concentration of $2 \mathrm{mM}$, unless otherwise stated. The flow rate of the superfusion was approx. $20 \mathrm{ml} / \mathrm{min}$, and a complete exchange of the bath solution was reached within about $10 \mathrm{~s}$ [45, 46].

\section{Chemiluminescence}

For detection of PEPT2-HA cell surface expression, the oocytes were first incubated with primary mouse monoclonal anti-HA antibody conjugated to horseradish peroxidase (1:1000, Miltenyi Biotec Inc, CA, USA). Individual oocytes were placed in 96 well plates with $20 \mu$ of SuperSignal ELISA Femto Maximum Sensitivity Substrate (Pierce) and chemiluminescence of single oocytes was quantified in a luminometer (Walter Wallac 2 plate reader, Perkin Elmer) by integrating the signal over a period of 1 sec [47]. Results display normalized relative light units. Integrity of the measured oocytes was assessed by visual control after the measurement to avoid unspecific light signals from the cytosol [48].

\section{Ussing chamber experiments}

All animal experiments were conducted according to the German law for the welfare of animals and according to the guidelines of the American Physiological Society and were approved by local authorities. Experiments have been performed using intestinal segments from 7-8 week old female gene targeted mice expressing SPAK resistant to WNK-dependent activation $\left(\right.$ spak $\left.^{t / / t g}\right)$ and in mice expressing wild-type SPAK $\left(\right.$ spak $\left.^{++}\right)$[38]. The mice were fed a control diet (1314, Altromin, Heidenau, Germany) and had free access to tap drinking water.

For analysis of electrogenic intestinal peptide transport, jejunal segments were mounted into a custom made mini-Ussing chamber with an opening of $0.00769 \mathrm{~cm}^{2}$. Under control conditions, the serosal and luminal perfusate contained (in mM): $115 \mathrm{NaCl}, 2 \mathrm{KCl}, 1 \mathrm{MgCl}_{2}, 1.25 \mathrm{CaCl}_{2}, 0.4 \mathrm{KH}_{2} \mathrm{PO}_{4}, 1.6 \mathrm{~K}_{2} \mathrm{HPO}_{4}, 5$ Sodium Pyruvate $\left(\mathrm{C}_{3} \mathrm{H}_{3} \mathrm{NaO}_{3}\right), 25 \mathrm{NaHCO}_{3}, 5$ mannitol $(\mathrm{pH} 7.4, \mathrm{NaOH})$. Where indicated, the dipeptide glycine-glycine $(5 \mathrm{mM})$ was added to the luminal perfusate at the expense of mannitol $(5 \mathrm{mM}$ ) (all substances were from Sigma, Schnelldorf, Germany, or from Roth, Karlsruhe, Germany).

In all Ussing chamber experiments the transepithelial potential difference (Vt) was determined continuously and the transepithelial resistance (Rt) was estimated from the voltage deflections $(\Delta \mathrm{Vt})$ elicited by imposing test currents ( $\mathrm{I}_{\mathrm{t}}$ ). The resulting Rt was calculated according to Ohm's law [40].

\section{Statistical analysis}

Data are provided as means \pm SEM, $n$ represents the number of oocytes or intestinal segments investigated. All voltage clamp experiments were repeated with at least 3 batches of oocytes; in all repetitions qualitatively similar data were obtained. Data were tested for significance using ANOVA (Tukey test or Kruskal-Wallis test) or t-test, as appropriate. Results with $\mathrm{p}<0.05$ were considered statistically significant.

\section{Results}

The present study explored whether SPAK participates in the regulation of peptide transport. To this end, cRNA encoding PEPT1 was injected into Xenopus laevis oocytes with or without additional injection of cRNA encoding wild-type, constitutively active or inactive SPAK. Peptide transport was estimated from the current generated by addition of the dipeptide glycine-glycine to the bath solution ( $\left.\mathrm{I}_{\text {gly-gly }}\right)$.

No appreciable $\mathrm{I}_{\text {gly-gly }}$ was observed in water injected Xenopus laevis oocytes (Fig. 1Aa,B). Accordingly, Xenopus laevis oocytes did not express measureable endogenous electrogenic glycine-glycine transport. As illustrated in Fig. 1, addition of glycine-glycine (2mM) to Xeno- 


\section{Kidney \\ Blood Pressure Research}

Kidney Blood Press Res 2014;39:388-398

DOI: 10.1159/000368451

Published onlıne: October 30, 2014

(C) 2014 S. Karger AG, Basel

www.karger.com/kbr
Fig. 1. Coexpression of SPAK decreases electrogenic peptide transport in PEPT1-expressing Xenopus laevis oocytes. A: Representative original tracings showing glycine-glycine $(2 \mathrm{mM})$ - induced current $\left(\mathrm{I}_{\text {gly-gly }}\right)$ in Xenopus laevis oocytes injected with water (a) or expressing PEPT1 without (b) or with additional coexpression of wild type SPAK (c). B: Arithmetic means \pm SEM ( $\mathrm{n}=$ $15)$ of glycine-glycine $(2 \mathrm{mM})$ induced current $\left(\mathrm{I}_{\text {gly-gly }}\right)$ in Xenopus laevis oocytes injected with water (light grey bar), or expressing PEPT1 without (white bar) or with wild-type SPAK (dark grey). ${ }^{*}(\mathrm{p}<0.05)$ indicates statistically significant difference from the absence of SPAK.

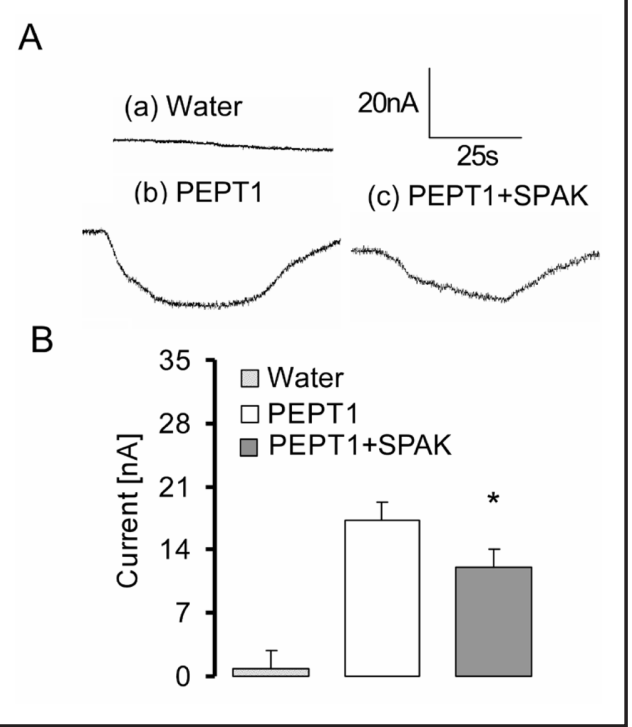

pus laevis oocytes injected with cRNA encoding PEPT1 was followed by appearance of $\mathrm{I}_{\mathrm{gly}-\mathrm{gly}}$. Additional expression of wild-type SPAK resulted in a significant decrease of $\mathrm{I}_{\text {gly-gly }}$ in PEPT1 expressing Xenopus laevis oocytes (Fig. 1).

In order to determine maximal transport rate and affinity of PEPT1, the oocytes were exposed to glycine-glycine concentrations ranging from 0.01 to $5 \mathrm{mM}$. As illustrated in Fig. 2, the increase of peptide concentration was followed by an increase of $\mathrm{I}_{\text {gly-gly }}$ in both, Xenopus laevis oocytes expressing PEPT1 alone and Xenopus laevis oocytes expressing PEPT1 and SPAK. The increase of $\mathrm{I}_{\text {gly-gly }}$ was, however, larger in Xenopus laevis oocytes expressing PEPT1 alone than in Xenopus laevis oocytes expressing PEPT1 with SPAK. Calculation of maximal currents utilizing the Michaelis Menten equation yielded values, which were significantly $(\mathrm{p}<0.01)$ lower in Xenopus laevis oocytes expressing PEPT1 together with SPAK $(22.4 \pm 1.6$ $\mathrm{nA}, \mathrm{n}=11-12)$, than in Xenopus laevis oocytes expressing PEPT1 alone $(31.2 \pm 2.4 \mathrm{nA}, \mathrm{n}=11$ 12). Calculation of glycine-glycine concentrations required for halfmaximal current $\left(\mathrm{K}_{\mathrm{M}}\right)$ did not yield significantly different values in Xenopus laevis oocytes expressing PEPT1 together with SPAK $(946 \pm 227 \mathrm{mM}, \mathrm{n}=11-12)$ and in Xenopus laevis oocytes expressing PEPT1 alone (795 $\pm 82 \mathrm{mM}, \mathrm{n}=11-12$ ) (Fig. 2).

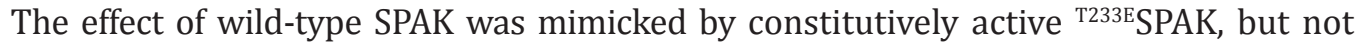
by WNK1 insensitive inactive ${ }^{\mathrm{T} 233 \mathrm{~A}} \mathrm{SPAK}$ and inactive kinase ${ }^{\mathrm{D} 212 \mathrm{~A} S P A K}$. As illustrated in Fig. 3 , coexpression of ${ }^{\mathrm{T} 233 \mathrm{E}} \mathrm{SPAK}$ but not coexpression of ${ }^{\mathrm{T} 233 \mathrm{~A}} \mathrm{SPAK}$ and ${ }^{\mathrm{D} 212 \mathrm{~A}} \mathrm{SPAK}$, significantly decreased $\mathrm{I}_{\text {gly-gly }}$ in PEPT1 expressing Xenopus laevis oocytes.

In order to test whether SPAK similarly regulates PEPT2, cRNA encoding PEPT2 was injected into Xenopus laevis oocytes with or without additional injection of cRNA encoding wild-type SPAK. As shown in Fig. 4, $\mathrm{I}_{\text {gly-gly }}$ was lower in oocytes expressing PEPT2 with wild-type SPAK than oocyte expressing PEPT2 alone (Fig.4).

Fig. 2. Coexpression of SPAK decreases maximal electrogenic peptide transport in PEPT1-expressing Xenopus laevis oocytes. A: Representative original tracings showing the current induced by increasing concentrations of glycine-glycine (from $10 \mu \mathrm{M}-5 \mathrm{mM}$ ) in Xenopus laevis oocytes expressing PEPT1 without (upper panel) or with (lower panel) additional coexpression of wild type SPAK. B: Arithmetic means \pm SEM ( $\mathrm{n}=$ 11-12) of glycine-glycine-induced current $\left(\mathrm{I}_{\text {gly-gly }}\right)$ as a function of glycine-glycine concentration in Xenopus laevis oocytes expressing PEPT1 without (black squares), or with (black circles) additional coexpression of wild-type SPAK. 


\section{Kidney \\ Blood Pressure Research}

A

\section{PEPT 1}

(i) $10 \mu \mathrm{M} \quad$ (ii) $100 \mu \mathrm{M} \quad$ (iii) $500 \mu \mathrm{M}$ (iv) $1000 \mu \mathrm{M}$ (v)2000
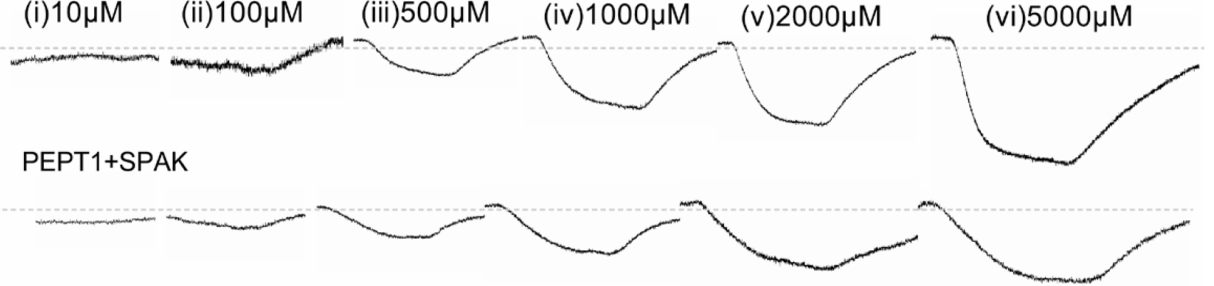

B


Fig. 3. The effect of SPAK is mimicked by active



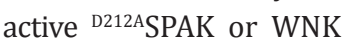
insensitive ${ }^{\mathrm{T} 233 \mathrm{~A}} \mathrm{SPAK}$. A: Representative original tracings showing glycine-glycine (2 mM) - induced current $\left(\mathrm{I}_{\text {gly-gly }}\right)$ in Xenopus laevis oocytes injected with water (a), expressing PEPT1 alone (b) or with additional coexpression of SPAK (c) or with constitutively active

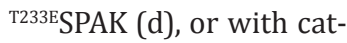
alytically inactive ${ }^{\mathrm{D} 212 \mathrm{~A} S}$ PAK (e) or with WNK1 in-


Arithmetic means \pm SEM ( $n=8-10)$ of glycine-glycine (2 mM) - induced current $\left(\mathrm{I}_{\text {gly-gly }}\right)$ in Xenopus laevis oocytes injected

with water (light grey bar) expressing PEPT1 without (white bar) or with wild-type SPAK (dark grey bar) or

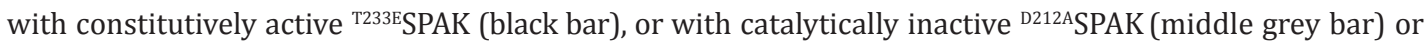

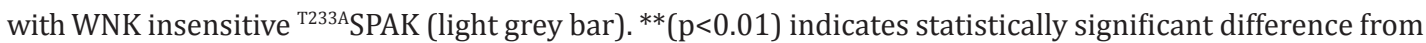
the absence of PEPT1.
A

(a) Water

(b) PEPT1

(c) PEPT1+SPAK

(d) PEPT1+ ${ }^{\text {T233E SPAK (e) PEPT1+D212ASPAK (f) PEPT1+ +233A SPAK }}$



B

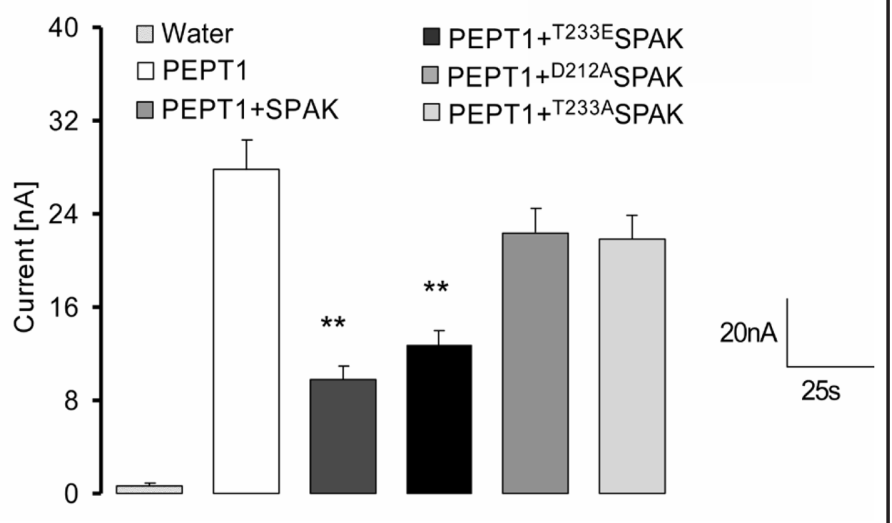




\section{Kidney \\ Blood Pressure Research}

Kidney Blood Press Res 2014;39:388-398

DOI: 10.1159/000368451

Published onlıne: October 30, 2014

(C) 2014 S. Karger AG, Basel

www.karger.com/kbr

Warsi/Dong/Elvira/Salker/Shumilina/Hosseinzadeh/Lang: SPAK Sensitive PEPT1/2 Activity
Fig. 4. Coexpression of SPAK decreases electrogenic peptide transport in PEPT2-expressing Xenopus laevis oocytes. A: Representative original tracings showing glycine-glycine $(2 \mathrm{mM})$ - induced current $\left(\mathrm{I}_{\text {gly-gly }}\right)$ in Xenopus laevis oocytes injected with water (a) or expressing PEPT2 without (b) or with additional coexpression of wild-type SPAK (c). B: Arithmetic means \pm SEM ( $n=$ 12 ) of glycine-glycine $(2 \mathrm{mM})$ - induced current $\left(\mathrm{I}_{\text {gly-gly }}\right)$ in Xenopus laevis oocytes injected with water (light grey bar), or expressing PEPT2 without (white bar) or with wild-type SPAK (dark grey bar). ${ }^{* *}(\mathrm{p}<0.01)$ indicates statistically significant difference from the absence of SPAK.

Fig. 5. SPAK coexpression decreases PEPT2 protein abundance in the Xenopus laevis oocyte cell membrane. Arithmetic means \pm SEM $(n=96-115)$ of PEPT2-HA protein abundance determined by chemiluminescence in Xenopus laevis oocytes injected with water (light grey bar) or expressing PEPT2-HA alone (white bar), or expressing PEPT2-HA together with wild-type SPAK (dark grey bar). ${ }^{*}(\mathrm{p}<0.05)$ indicates statistically significant difference from Xenopus laevis oocytes expressing PEPT2-HA alone (Kruskal-Wallis test).


The down-regulation of $\mathrm{I}_{\text {gly-gly }}$ in PEPT1 or PEPT2-expressing Xenopus laevis oocytes following coexpression of SPAK could have resulted from a decline of protein abundance in the cell membrane. Thus, chemiluminescence was employed to quantify the carrier protein abundance in the cell membrane. As illustrated in Fig. 5, coexpression of wild-type SPAK resulted in a significant decrease of the PEPT2 protein abundance in the cell membrane of PEPT2 expressing Xenopus laevis oocytes.

Additional experiments were performed to determine the stability of $\mathrm{I}_{\text {gly-gly }}$ following disruption of new carrier protein insertion into the cell membrane by Brefeldin $A(5 \mu \mathrm{M})$. As

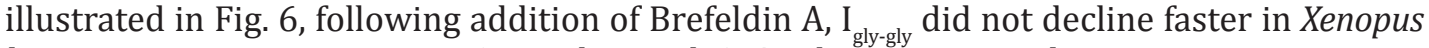
laevis oocytes expressing PEPT1 together with SPAK than in Xenopus laevis oocytes expressing PEPT1 alone. Thus, SPAK decreased $\mathrm{I}_{\text {gly-gly }}$ by a mechanism other than accelerating carrier clearance from the cell membrane.

In order to define the in vivo significance of SPAKsensitive regulation of peptide transporters, peptide induced current was determined in Ussing chamber experiments of intestinal segments isolated from 16-week-old female gene targeted mice carrying WNK insensitive SPAK (spak ${ }^{\text {tg/ }}$ ${ }^{t g}$ ) or corresponding wild-type mice $\left(\operatorname{spak}^{+/+}\right)$. As illustrated in Fig. 7, addition of glycineglycine $(5 \mathrm{mM})$ to the luminal perfusate generated a transepithelial current $\left(\mathrm{I}_{\text {gly-gly }}\right)$, which was significantly higher in intestinal epithelium from spak $k^{\text {tg/tg }}$ mice than from $s p a k^{+/+}$mice. 


\section{Kidney \\ Blood Pressure Research}

Kidney Blood Press Res 2014;39:388-398

\begin{tabular}{l|l}
\hline DOI: 10.1159/000368451 & $\begin{array}{l}\text { C 2014 S. Karger AG, Basel } \\
\text { www.karger.com/kbr }\end{array}$ \\
Published onlIne: October 30, 2014 &
\end{tabular}

Activity

Fig. 6. Coexpression of SPAK does not accelerate the decline of electrogenic peptide transport in the presence of Brefeldin A in PEPT1 expressing oocytes. Arithmetic means \pm SEM $(n=10-13)$ of glycineglycine $(2 \mathrm{mM})$ - induced current $\left(\mathrm{I}_{\text {gly-gly }}\right)$ in Xenopus laevis oocytes injected with cRNA encoding PEPT1 without (PEPT1, white bars) or with (PEPT1+SPAK, grey bars) wild-type SPAK and exposed to $5 \mu \mathrm{M}$ Brefeldin A for the indicated time periods. ${ }^{* *}(\mathrm{p}<0.01) \quad$ indicates statistically significant difference from the absence of SPAK; \#\#\#( $<0.01)$ indicates statistically significant difference from the absence of Brefeldin A.

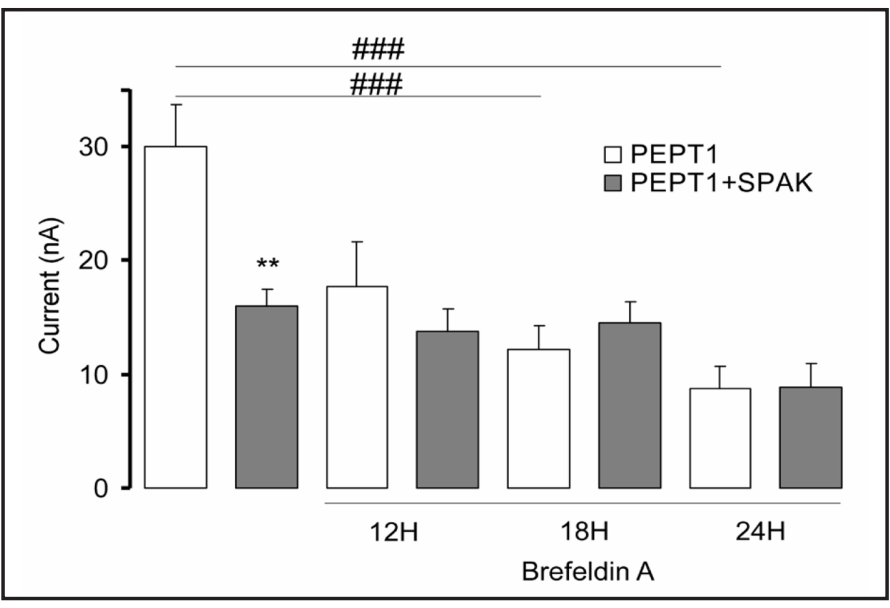

Fig. 7. Glycine-glycine-induced current is increased in intestinal segments from SPAK-deficient mice. A: Original representative tracings illustrating the effect of $5 \mathrm{mM}$ glycine-glycine on the transepithelial potential difference across jejunal segments from (A) SPAK corresponding wild-type mice $\left(\right.$ spak $\left.^{++}\right)$and (B) gene targeted mice expressing SPAK resistant to WNK-dependent activation $\left(\right.$ spak $\left.^{t g / t g}\right)$. Arrows indicate addition of GlyGly. Throughout the experiments test currents of $1 \mu \mathrm{A}$ were applied to allow determination of transepithelial resistance. B: Arithmetic means \pm SEM $(n=5)$ of glycine-glycine $(5 \mathrm{mM})$ induced current $\left(\mathrm{I}_{\text {gly-gly }}\right)$ in jejunum from $\operatorname{spak}^{+/+}$( white bar ) and spak ${ }^{\text {tg/tg }}$, (black bar) mice.

* indicates statistically significant $(\mathrm{p}<0.05)$ difference from wild-type mice (Students t-test).

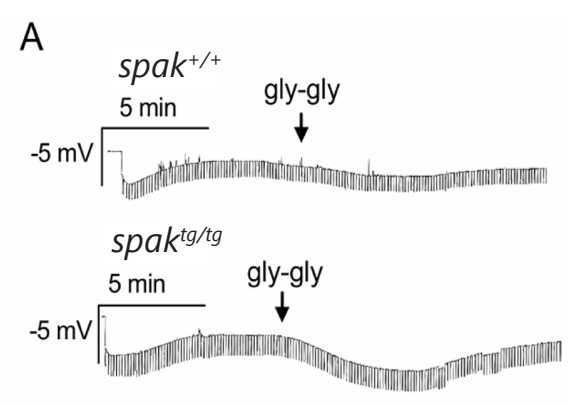

B



\section{Discussion}

The present study reveals that SPAK (STE20-related proline/alanine-rich kinase) downregulates the peptide transporters PEPT1 and PEPT2. Coexpression of SPAK, of constitutively

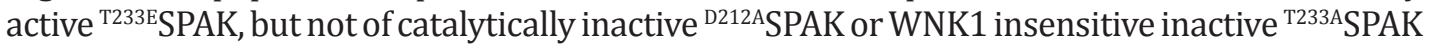
was followed by a decrease of electrogenic dipeptide transport in PEPT1 expressing Xenopus

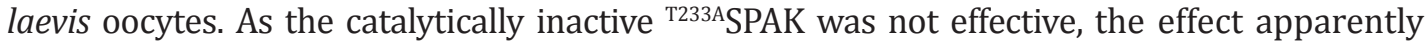
requires kinase activity. The effect on PEPT2 resulted at least in part from a decrease of PEPT2 protein abundance in the cell membrane. The experiments with Brefeldin A suggest that SPAK was not effective by enhancing PEPT1 carrier retrieval from the cell membrane and are compatible with the assumption that SPAK delayed carrier insertion into the cell membrane. 


\section{Kidney \\ Blood Pressure Research}

Kidney Blood Press Res 2014;39:388-398

\begin{tabular}{l|l}
\hline DOI: $10.1159 / 000368451$ & (C) 2014 S. Karger AG, Basel
\end{tabular}

Published onlıne: October 30, 2014

www.karger.com/kbr

Activity

The down-regulating effect of SPAK on the peptide transporters is in seeming contrast to the upregulation of the $\mathrm{Na}^{+}, \mathrm{Cl}^{-}(\mathrm{NCC})$ and the $\mathrm{Na}^{+}, \mathrm{K}^{+}, 2 \mathrm{Cl}^{-}$(NKCC2) cotransporters [14, 15, 18, 23-33]. Presumably, the mechanisms involved in the regulation of the peptide transporters are distinct from those regulating NCC and NKCC. SPAK influences NCC and NKCC at least in part by direct phosphorylation of the carrier protein [33]. The mechanism underlying SPAK sensitivity of the peptide transporters remains to be identified. The in vivo significance of the observations in Xenopus laevis oocytes is underscored by the observation that the peptide induced current was higher in $s p a k^{\text {tg/tg }}$ than in $s p a k^{+/+}$mice. The possibility should be kept in mind, though, that SPAK deficiency may indirectly modify intestinal peptide transport.

The peptide transporters significantly contribute to intestinal nutrient uptake [2, 49], and the majority of dietary nitrogen is taken up by PEPT1 [50]. Thus, SPAK sensitivity of PEPT1 is expected to impact on intestinal nutrient transport.

At least in theory, the impact of SPAK on intestinal peptide transport may be particularly relevant for altered intestinal transport in intestinal inflammation, which involves altered intestinal SPAK [51] and PEPT1 [3] activity. In the absence of inflammation, PEPT1 expression is restricted to small intestine [3]. PEPT1 is, however, highly expressed in colon following inflammatory bowel disease (IBD) [3].

SPAK interacts with several kinases, such as p38 kinase, Jun activated kinase (JNK), protein kinase $\mathrm{C}$ theta (PKCtheta), with no K kinase (WNK) and myosin light chain kinase (MLCK), kinases participating in the signalling of cell differentiation, cell transformation, cell proliferation, and cytoskeleton architecture [51]. Whether or not SPAK modifies cellular peptide uptake during differentiation, cell transformation and/or cell proliferation, remains to be shown. Whether sensitivity of SPAK activity to cell volume $[24,36]$ impacts on the regulation of peptide transporters, similarly remains to be shown.

Peptide transporters mediate the transport of several drugs including beta-lactam antibiotics, angiotensin-converting enzyme inhibitors, antiviral drugs, and anti-cancer agents $[2,49,52-55]$. Peptide transporters are thus not only important for cellular nutrient uptake but as well for cellular drug uptake $[1,10,56,57]$. The transporters are, for instance, expressed in pancreatic cancer cells [58] and prostate cancer cells [59] and the carriers have been considered potential targets for tumor therapy [59]. Whether or not drug uptake into tumor cells is sensitive to SPAK, remains to be shown.

\section{Conclusion}

The present observations reveal a powerful effect of SPAK on the activity of the peptide transporters, PEPT1 and PEPT2. As shown for PEPT2, the kinase is effective by decreasing carrier protein abundance in the cell membrane. SPAK sensitive regulation of peptide transporters may be relevant for cellular peptide and xenobiotic uptake in intestine and presumably other polarized or non-polarized cell types.

\section{Disclosure Statement}

The authors state that they do not have any conflicts of interest.

\section{Acknowledgements}

The authors acknowledge the meticulous preparation of the manuscript by Ali Soleimanpour and Tanja Loch and technical support by Elfriede Faber. This study was supported by the Deutsche Forschungsgemeinschaft, GRK 1302, SFB 773 B4/A1, La 315/13-3 and the Open Access Publishing Fund of Tuebingen University. 


\section{Kidney \\ Blood Pressure Research}

Kidney Blood Press Res 2014;39:388-398

\begin{tabular}{l|l}
\hline DOI: $10.1159 / 000368451$ & (C) 2014 S. Karger AG, Basel
\end{tabular}

Publisned ontrne: Uctober 30, 2014

www.karger.com/kbr

Warsi/Dong/Elvira/Salker/Shumilina/Hosseinzadeh/Lang: SPAK Sensitive PEPT1/2 Activity

\section{References}

1 Inoue M, Terada T, Okuda M, Inui K: Regulation of human peptide transporter 1 (PEPT1) in gastric cancer cells by anticancer drugs. Cancer Lett 2005;230:72-80.

-2 Rubio-Aliaga I, Daniel H: Peptide transporters and their roles in physiological processes and drug disposition. Xenobiotica 2008;38:1022-1042.

3 Ingersoll SA, Ayyadurai S, Charania MA, Laroui H, Yan Y, Merlin D: The role and pathophysiological relevance of membrane transporter PepT1 in intestinal inflammation and inflammatory bowel disease. Am J Physiol Gastrointest Liver Physiol 2012;302:G484-G492.

4 Smith DE, Clemencon B, Hediger MA: Proton-coupled oligopeptide transporter family SLC15: physiological, pharmacological and pathological implications. Mol Aspects Med 2013;34:323-336.

-5 Nielsen CU, Brodin B: Di/tri-peptide transporters as drug delivery targets: regulation of transport under physiological and patho-physiological conditions. Curr Drug Targets 2003;4:373-388.

-6 Yarandi SS, Hebbar G, Sauer CG, Cole CR, Ziegler TR: Diverse roles of leptin in the gastrointestinal tract: modulation of motility, absorption, growth, and inflammation. Nutrition 2011;27:269-275.

7 Alteheld B, Evans ME, Gu LH, Ganapathy V, Leibach FH, Jones DP, Ziegler TR: Alanylglutamine dipeptide and growth hormone maintain PepT1-mediated transport in oxidatively stressed Caco-2 cells. J Nutr 2005;135:19-26.

8 Rexhepaj R, Rotte A, Pasham V, Gu S, Kempe DS, Lang F: PI3 kinase and PDK1 in the regulation of the electrogenic intestinal dipeptide transport. Cell Physiol Biochem 2010;25:715-722.

-9 Boehmer C, Palmada M, Klaus F, Jeyaraj S, Lindner R, Laufer J, Daniel H, Lang F: The peptide transporter PEPT2 is targeted by the protein kinase SGK1 and the scaffold protein NHERF2. Cell Physiol Biochem 2008;22:705-714.

10 Pieri M, Christian HC, Wilkins RJ, Boyd CA, Meredith D: The apical (hPepT1) and basolateral peptide transport systems of Caco-2 cells are regulated by AMP-activated protein kinase. Am J Physiol Gastrointest Liver Physiol 2010;299:G136-G143.

-11 Rafiqi FH, Zuber AM, Glover M, Richardson C, Fleming S, Jovanovic S, Jovanovic A, O'Shaughnessy KM, Alessi DR: Role of the WNK-activated SPAK kinase in regulating blood pressure. EMBO Mol Med 2010;2:63-75.

12 Castaneda-Bueno M, Gamba G: SPAKling insight into blood pressure regulation. EMBO Mol Med 2010;2:3941.

13 Yang SS, Lo YF, Wu CC, Lin SW, Yeh CJ, Chu P, Sytwu HK, Uchida S, Sasaki S, Lin SH: SPAK-knockout mice manifest Gitelman syndrome and impaired vasoconstriction. J Am Soc Nephrol 2010;21:1868-1877.

14 Vitari AC, Deak M, Morrice NA, Alessi DR: The WNK1 and WNK4 protein kinases that are mutated in Gordon's hypertension syndrome phosphorylate and activate SPAK and OSR1 protein kinases. Biochem J 2005;391:1724.

15 Vitari AC, Thastrup J, Rafiqi FH, Deak M, Morrice NA, Karlsson HK, Alessi DR: Functional interactions of the SPAK/OSR1 kinases with their upstream activator WNK1 and downstream substrate NKCC1. Biochem J 2006;397:223-231.

16 Glover M, Zuber AM, O'Shaughnessy KM: Hypertension, dietary salt intake, and the role of the thiazidesensitive sodium chloride transporter NCCT. Cardiovasc Ther 2011;29:68-76.

17 O'Reilly M, Marshall E, Speirs HJ, Brown RW: WNK1, a gene within a novel blood pressure control pathway, tissue-specifically generates radically different isoforms with and without a kinase domain. J Am Soc Nephrol 2003;14:2447-2456.

18 Kahle KT, Rinehart J, Lifton RP: Phosphoregulation of the Na-K-2Cl and K-Cl cotransporters by the WNK kinases. Biochim Biophys Acta 2010;1802:1150-1158.

19 Flatman PW: Cotransporters, WNKs and hypertension: an update. Curr Opin Nephrol Hypertens 2008;17:186192.

-20 Furgeson SB, Linas S: Mechanisms of type I and type II pseudohypoaldosteronism. J Am Soc Nephrol 2010;21:1842-1845.

21 Uchida S: Pathophysiological roles of WNK kinases in the kidney. Pflugers Arch 2010;460:695-702.

22 Wilson FH, Disse-Nicodeme S, Choate KA, Ishikawa K, Nelson-Williams C, Desitter I, Gunel M, Milford DV, Lipkin GW, Achard JM, Feely MP, Dussol B, Berland Y, Unwin RJ, Mayan H, Simon DB, Farfel Z, Jeunemaitre X, Lifton RP: Human hypertension caused by mutations in WNK kinases. Science 2001;293:1107-1112. 


\section{Kidney \\ Blood Pressure Research}

23 Delpire E, Gagnon KB: SPAK and OSR1, key kinases involved in the regulation of chloride transport. Acta Physiol (Oxf) 2006;187:103-113.

-24 Delpire E, Gagnon KB: SPAK and OSR1: STE20 kinases involved in the regulation of ion homoeostasis and volume control in mammalian cells. Biochem J 2008;409:321-331.

25 Gimenez I: Molecular mechanisms and regulation of furosemide-sensitive Na-K-Cl cotransporters. Curr Opin Nephrol Hypertens 2006;15:517-523.

-26 Richardson C, Sakamoto K, de los HP, Deak M, Campbell DG, Prescott AR, Alessi DR: Regulation of the NKCC2 ion cotransporter by SPAK-OSR1-dependent and -independent pathways. J Cell Sci 2011;124:789-800.

-27 Gagnon KB, Delpire E: On the substrate recognition and negative regulation of SPAK, a kinase modulating Na+-K+-2Cl- cotransport activity. Am J Physiol Cell Physiol 2010;299:C614-C620.

-28 Glover M, O'Shaughnessy KM: SPAK and WNK kinases: a new target for blood pressure treatment? Curr Opin Nephrol Hypertens 2011;20:16-22.

29 Lin SH, Yu IS, Jiang ST, Lin SW, Chu P, Chen A, Sytwu HK, Sohara E, Uchida S, Sasaki S, Yang SS: Impaired phosphorylation of $\mathrm{Na}(+)-\mathrm{K}(+)-2 \mathrm{Cl}(-)$ cotransporter by oxidative stress-responsive kinase-1 deficiency manifests hypotension and Bartter-like syndrome. Proc Natl Acad Sci USA 2011;108:17538-17543.

-30 Mercier-Zuber A, O'Shaughnessy KM: Role of SPAK and OSR1 signalling in the regulation of $\mathrm{NaCl}$ cotransporters. Curr Opin Nephrol Hypertens 2011;20:534-540.

-31 Richardson C, Alessi DR: The regulation of salt transport and blood pressure by the WNK-SPAK/OSR1 signalling pathway. J Cell Sci 2008;121:3293-3304.

-32 Villa F, Deak M, Alessi DR, van Aalten DM: Structure of the OSR1 kinase, a hypertension drug target. Proteins 2008;73:1082-1087.

33 Huang CL, Yang SS, Lin SH: Mechanism of regulation of renal ion transport by WNK kinases. Curr Opin Nephrol Hypertens 2008;17:519-525.

-34 Achard JM, Disse-Nicodeme S, Fiquet-Kempf B, Jeunemaitre X: Phenotypic and genetic heterogeneity of familial hyperkalaemic hypertension (Gordon syndrome). Clin Exp Pharmacol Physiol 2001;28:1048-1052.

-35 Capasso G, Cantone A, Evangelista C, Zacchia M, Trepiccione F, Acone D, Rizzo M: Channels, carriers, and pumps in the pathogenesis of sodium-sensitive hypertension. Semin Nephrol 2005;25:419-424.

-36 Hoffmann EK, Schettino T, Marshall WS: The role of volume-sensitive ion transport systems in regulation of epithelial transport. Comp Biochem Physiol A Mol Integr Physiol 2007;148:29-43.

-37 Pathare G, Foller M, Daryadel A, Mutig K, Bogatikov E, Fajol A, Almilaji A, Michael D, Stange G, Voelkl J, Wagner CA, Bachmann S, Lang F: OSR1-sensitive renal tubular phosphate reabsorption. Kidney Blood Press Res 2012;36:149-161.

-38 Pathare G, Foller M, Michael D, Walker B, Hierlmeier M, Mannheim JG, Pichler BJ, Lang F: Enhanced FGF23 serum concentrations and phosphaturia in gene targeted mice expressing WNK-resistant SPAK. Kidney Blood Press Res 2012;36:355-364.

-39 Pasham V, Rotte A, Yang W, Zelenak C, Bhandaru M, Foller M, Lang F: OSR1-sensitive regulation of Na+/H+ exchanger activity in dendritic cells. Am J Physiol Cell Physiol 2012;303:C416-426.

40 Hosseinzadeh Z, Dong L, Bhavsar SK, Warsi J, Almilaji A, Lang F: Upregulation of peptide transporters PEPT1 and PEPT2 by Janus kinase JAK2. Cell Physiol Biochem 2013;31:673-682.

-41 Dermaku-Sopjani M, Almilaji A, Pakladok T, Munoz C, Hosseinzadeh Z, Blecua M, Sopjani M, Lang F: Downregulation of the Na-coupled phosphate transporter NaPi-IIa by AMP-activated protein kinase. Kidney Blood Press Res 2013;37:547-556.

42 Alesutan I, Sopjani M, Dermaku-Sopjani M, Munoz C, Voelkl J, Lang F: Upregulation of Na-coupled glucose transporter SGLT1 by Tau tubulin kinase 2. Cell Physiol Biochem 2012;30:458-465.

43 Henrion U, Zumhagen S, Steinke K, Strutz-Seebohm N, Stallmeyer B, Lang F, Schulze-Bahr E, Seebohm G: Overlapping cardiac phenotype associated with a familial mutation in the voltage sensor of the KCNQ1 channel. Cell Physiol Biochem 2012;29:809-818.

44 Hosseinzadeh Z, Bhavsar SK, Lang F: Downregulation of ClC-2 by JAK2. Cell Physiol Biochem 2012;29:737742.

45 Bogatikov E, Munoz C, Pakladok T, Alesutan I, Shojaiefard M, Seebohm G, Foller M, Palmada M, Bohmer C, Broer S, Lang F: Up-regulation of amino acid transporter SLC6A19 activity and surface protein abundance by PKB/Akt and PIKfyve. Cell Physiol Biochem 2012;30:1538-1546. 


\section{Kidney \\ Blood Pressure Research}

\section{Kidney Blood Press Res 2014;39:388-398}

DOI: 10.1159/000368451

Published onlıne: October 30, 2014

C 2014 S. Karger AG, Basel

www.karger.com/kbr Activity

46 Hosseinzadeh Z, Bhavsar SK, Lang F: Down-regulation of the myoinositol transporter SMIT by JAK2. Cell Physiol Biochem 2012;30:1473-1480.

47 Mia S, Munoz C, Pakladok T, Siraskar G, Voelkl J, Alesutan I, Lang F: Downregulation of Kv1.5 K channels by the AMP-activated protein kinase. Cell Physiol Biochem 2012;30:1039-1050.

-48 Pakladok T, Almilaji A, Munoz C, Alesutan I, Lang F: PIKfyve sensitivity of hERG channels. Cell Physiol Biochem 2013;31:785-794.

49 Meredith D: Review. The mammalian proton-coupled peptide cotransporter PepT1: sitting on the transporter-channel fence? Philos Trans R Soc Lond B Biol Sci 2009;364:203-207.

$\rightarrow 50$ Foley DW, Rajamanickam J, Bailey PD, Meredith D: Bioavailability through PepT1: the role of computer modelling in intelligent drug design. Curr Comput Aided Drug Des 2010;6:68-78.

51 Yan Y, Merlin D: Ste20-related proline/alanine-rich kinase: a novel regulator of intestinal inflammation. World J Gastroenterol 2008;14:6115-6121.

-52 Newstead S: Towards a structural understanding of drug and peptide transport within the proton-dependent oligopeptide transporter (POT) family. Biochem Soc Trans 2011;39:1353-1358.

53 Brandsch M: Transport of drugs by proton-coupled peptide transporters: pearls and pitfalls. Expert Opin Drug Metab Toxicol 2009;5:887-905.

54 Kamal MA, Keep RF, Smith DE: Role and relevance of PEPT2 in drug disposition, dynamics, and toxicity. Drug Metab Pharmacokinet 2008;23:236-242.

55 Nakamura T, Yamamori M, Sakaeda T: Pharmacogenetics of intestinal absorption. Curr Drug Deliv 2008;5:153-169.

56 Mitsuoka K, Kato Y, Miyoshi S, Murakami Y, Hiraiwa M, Kubo Y, Nishimura S, Tsuji A: Inhibition of oligopeptide transporter suppress growth of human pancreatic cancer cells. Eur J Pharm Sci 2010;40:202-208.

-57 Tsume Y, Hilfinger JM, Amidon GL: Enhanced cancer cell growth inhibition by dipeptide prodrugs of floxuridine: increased transporter affinity and metabolic stability. Mol Pharm 2008;5:717-727.

58 Gonzalez DE, Covitz KM, Sadee W, Mrsny RJ: An oligopeptide transporter is expressed at high levels in the pancreatic carcinoma cell lines AsPc-1 and Capan-2. Cancer Res 1998;58:519-525.

59 Tai W, Chen Z, Cheng K: Expression Profile and Functional Activity of Peptide Transporters in Prostate Cancer Cells. Mol Pharm 2013;10:477-487. 